\title{
Comparative Study of Total Harmonic Distortion in Multilevel Inverters Based WECS
}

\author{
B Kandavel ${ }^{1 *}$, G Uvaraj ${ }^{2}$, M Manikandan ${ }^{3}$ \\ ${ }^{1,2}$ Research Scholar/EEE, SCSVMV, Kanchipuram, India \\ ${ }^{3}$ Associate Professor/ECE, MIT, Anna University, Chennai, India \\ *Corresponding author E-mail: kanda71@gmail.com
}

\begin{abstract}
This paper presents comparative study of Total Harmonic Distortion (THD) and its individual harmonic contents without grid and with grid for Diode clamped multi level inverter (DCMLI) and Flying capacitor clamped multilevel inverter (FCMLI) based Doubly Fed Induction Generator (DFIG) employing PI and Fuzzy logic controller (FLC). Simple method to control for a variable speed wind energy conversion system with a DFIG is connected to the grid through a diode rectifier and a diode clamped multilevel inverter (DCMLI). The DC-link voltage is controlled through a DC-DC boost converter to keep the DC voltage at constant value. Inverter is controlled by sinusoidal pulse width modulation technique, which supplies power to the grid. The THD and its harmonic content are studied for different wind speeds. DFIG fed flying capacitor multi level inverter (FCMLI) based WECS connected to load as well as grid. FCMLI is controlled through sinusoidal pulse width modulation. Voltage and current harmonics are studied. The results of both multilevel inverters are compared. It shows that the level of harmonic content of two types of multilevel inverters working at different wind speeds indicates that Total Harmonic Distortion (THD) for DCMLI has given best results.
\end{abstract}

Keywords: DCMLI, FCMLI, Harmonics and THD.

\section{Introduction}

The fossil fuel prices are rapidly increasing, that had affected the economic growth of many developing countries. The burning of fossil fuels will emit the green house gases, it will affect the global climate. So we have to reduce this green house gas emission effect to improve the global climate change. There is a need for alternative energy sources which does not emit any green house emission. Wind power is one of the purest sources of renewable energy or green energy. Energy demands are growing day by day, wind power shows potential alternatives to fossil fuels. Harmonics have become a major issue in the recent times due to the high usage of power electronic equipment. Harmonics lead to various problems such as overheating of equipment, interference with the nearby communication lines, high power loss, low power factor and hence poor usage of equipment. The increasing use of power electronics and converters (particularly for wind turbines) are injecting more harmonic currents onto the system. Harmonics can damage users' and system equipment. They may also interfere with telecommunication lines. Harmonics cause higher losses through increased currents in the power system. To diminish these harmonics, desirable filter is required. There are two types of filters that are usually used, active and passive filters. To block lower harmonics orders we have to go for band pass filters and to filter higher harmonics high pass filters are generally used. Wind energy conversion system does not pollute the atmosphere does not emit any green house gases. Wind energy conversion system based on a doubly fed induction generator (DFIG) are normally used. The WECS is consists of wind turbine rotor, the drive train and the DFIG. The DFIG is connected to the grid through the stator, its rotor is connected to the grid through diode clamped multilevel inverter. The energy transfer from DFIG to grid via diode clamped multilevel inverter and flying capacitor based multilevel inverter. Sinusoidal Pulse Width Modulation (SPWM)based DCMLI is linked by DC link capacitor is connected in between the dc to dc converter. The aim of this work is to compare the total harmonic distortion and its individual harmonic contents obtained from the DCMLI and FCMLI based wind energy conversion system(WECS).

\section{Wind Turbine Modelling}

The wind turbine extracts the energy from the moving air. The power in the air for blade swept area A is estimated by

$\mathrm{P}_{\text {air }}=\frac{1}{2} \rho A V^{3}$ wind

Where,

$\mathrm{P}_{\text {air }}$ :Power in the wind, $\rho:$ air density,

A:swept area of the rotor, $V_{\text {wind }}$ : wind speed.

$\mathrm{P}_{\text {wind }}=\mathrm{C}_{\mathrm{P}} \mathrm{P}_{\text {air }}$

$\mathrm{P}_{\text {wind }}=\mathrm{C}_{\mathrm{P}}^{\frac{1}{2}} \rho \mathrm{AV}^{3}$ wind

A maximum value of $\mathrm{Cp}$ is defined by the Betz limit, which states that aturbine can never extract more than $59.3 \%$ of the power from an air stream. In reality, wind turbine rotors have maximum $\mathrm{Cp}$ values in the range $25-45 \%$.It is also conventional to define a tipspeed ratio, $\lambda$, as 


$$
\lambda=\frac{\square \mathrm{K}}{\mathrm{w}}
$$

$\omega$ - rotational speed of rotor

$\mathrm{R}$ - radius of tip of rotor

$\mathrm{V}$ - wind speed

The tip-speed ratio, $\lambda$, and the power coefficient, $\mathrm{Cp}$, are dimensionless andso can be used to describe the performance of any size of wind turbine rotor. The maximum power coefficient is only achieved at a single tip-speed ratio and for a fixed rotational speed of the wind turbine this only occurs at a single wind speed.

\section{DFIG Modeling}

The control system is usually defined in the synchronous $d-q$ frame fixed to either the stator voltage or the stator flux. For the proposed control strategy, the generator dynamic model written in a synchronously rotating frame $d-q$.DFIG based wind energy conversion system with back to back converter with the electric grid The stator of the DFIG is directly connected to the grid, through slip rings and brushes. The three phase rotor winding is connected through the back-to-back converter with a common DC link bus. Grid side converter has to keep dc link capacitor voltage at constant value. The rotor side converter controls active and reactive power to the grid. For the variable speed operation, we have to track the torque and speed. By controlling the torque we can get the desired speed. Fuzzy logic controller and PI Controller employed to measure desired electrical quantities for load and grid connection and THD and its individual harmonic contents are studied

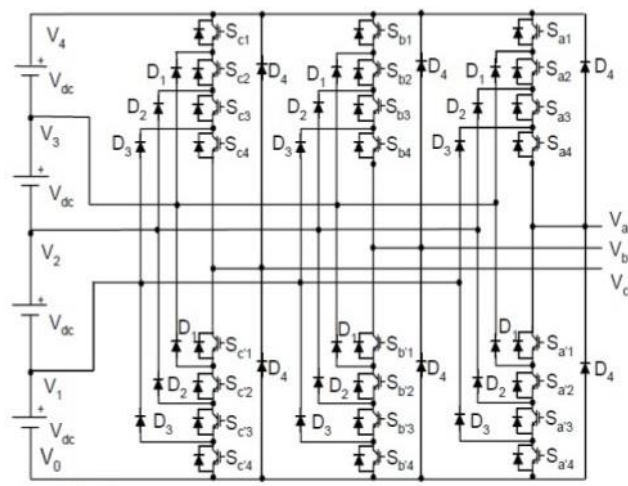

Fig. 1: Five Level Diode Clamped Multilevel Inverter

A 3-phase five-level diode-clamped inverter is shown in Fig. 1.The three phases of the inverter has a common dc bus, which has been subdivided by four capacitors into five levels. The voltage in each capacitor is Vdc and through the clamping diodes the voltage stress in each switching device is limited to Vdc. Table 1 lists the output voltage levels possible for one phase of the inverter $\mathrm{V}_{0}$ as a reference. State condition 1 means the switch is on, and 0 means the switch is off. Each phase has four complementary switch pairs.Turning on one of the switches of the pair requires that the other complementary switch be turned off. The complementary switch pairs for phase c are (Sc1, Sc'1), (Sc2, Sc'2), (Sc3, Sc'3), (Sc4, Sc'4).In a diode-clamped inverter, the switches that are on for any phase leg are always adjacent as well as series. For a five level inverter, a set of four switches is on at any given time.

Table 1: Diode-clamped five level inverter switch states

\begin{tabular}{|c|c|c|c|c|c|c|c|c|}
\hline \multirow{2}{*}{$\begin{array}{c}\text { Voltage } \\
\text { Vao }\end{array}$} & \multicolumn{8}{|c|}{ Switch State } \\
\hline & S & $\mathrm{S}$ & $\mathrm{S}$ & $\mathrm{S}$ & $\begin{array}{r}\mathrm{S} \\
c^{\prime} 4\end{array}$ & $\begin{array}{r}\mathrm{S} \\
c^{\prime} 3\end{array}$ & $\begin{array}{r}\mathrm{S} \\
c^{\prime} 2\end{array}$ & $\begin{array}{r}\mathrm{S} \\
c^{\prime} 1\end{array}$ \\
\hline V4 & 1 & 1 & 1 & 1 & 0 & 0 & 0 & 0 \\
\hline V3 & 0 & 1 & 1 & 1 & 1 & 0 & 0 & 0 \\
\hline $\mathrm{V} 2$ & 0 & 0 & 1 & 1 & 1 & 1 & 0 & 0 \\
\hline V1 & 0 & 0 & 0 & 1 & 1 & 1 & 1 & 0 \\
\hline V0 & 0 & 0 & 0 & 0 & 1 & 1 & 1 & 1 \\
\hline
\end{tabular}

DFIG output both voltage and frequency are controlled by operating the wind turbine at its maximum power point. This model DFIG fed DCMLI was developed in a Matlab/Simulink environment. Fuzzy logic controller and PI Controller employed to measure desired electrical quantities for load and grid connection and THD and its individual harmonic contents are studied.

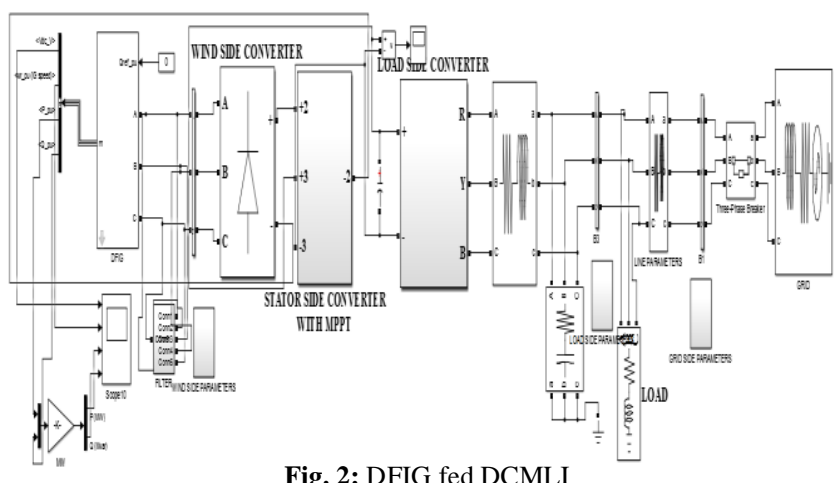

Fig. 2: DFIG fed DCMLI

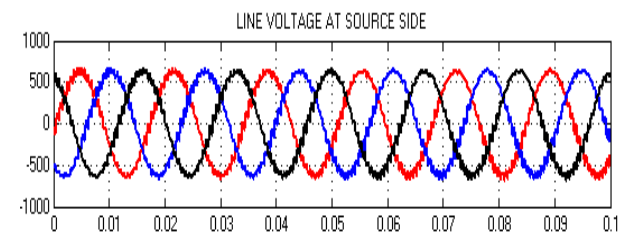

Fig. 3: Line voltage at source side

LNEEVOLTGESAT DISTRBDUTIONSIDE

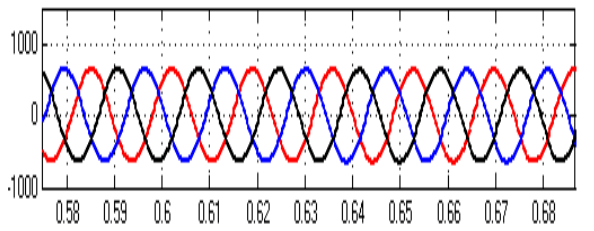

Fig. 4: Line voltage at Distribution side

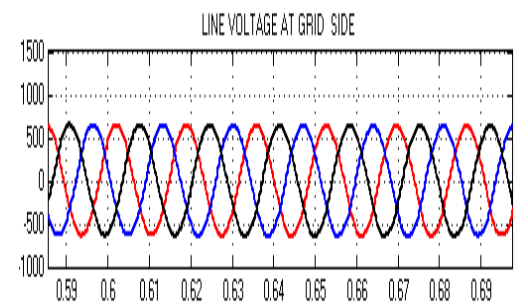

Fig. 5: Line voltage at Grid Side

LNEE CURRENT AT DISTRIBUTION SIDE

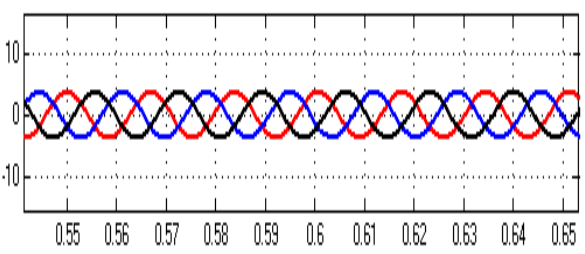

Fig. 6: Line Current at Distribution Side 


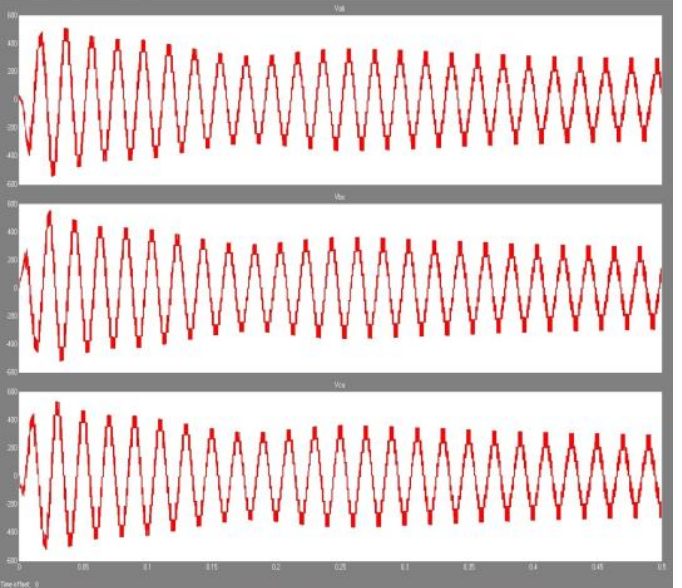

Fig. 7: Output voltage of DCMLI

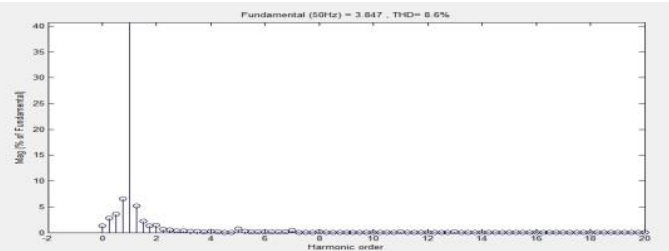

Fig. 8: Current Harmonics for FCMLI (PI)

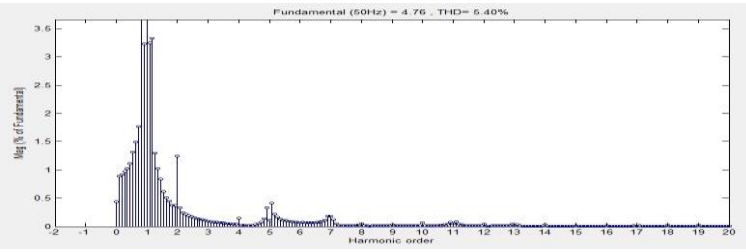

Fig. 9: Current Harmonics for FCMLI (FLC)

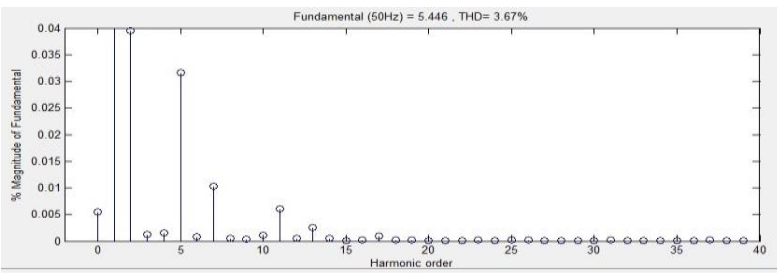

Fig. 10: Current Harmonics for DCMLI (PI)

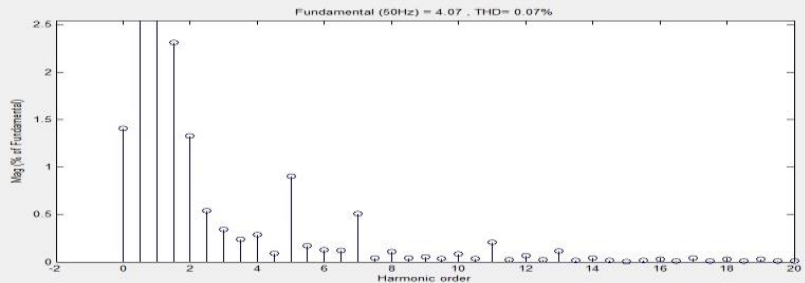

Fig. 11: Current Harmonics for DCMLI (FLC)

\section{Flying Capacitor Clamped Inverter Based WECS}

The configuration of this inverter is analogous to the diodeclamped inverter except that instead of using clamping diodes, the inverter uses capacitors in their place. The circuit topology of the flying-capacitor multilevel inverter is shown in Fig.12. The voltage on each capacitor differs from the next capacitor this circuit is likes a ladder arrangement of dc capacitors. The voltage increase between two neighboring capacitor legs gives the voltage levels in the output. We need $(m-1)$ dc link capacitors for the m-level. FCMLI will need $(\mathrm{m}-1) \times(\mathrm{m}-2) / 2$ auxiliary capacitors per phase if the voltage rating of the capacitors and switches are the same.

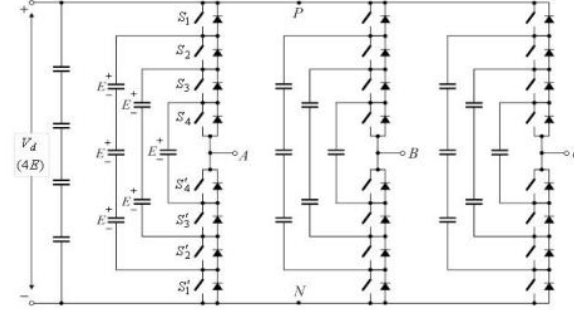

Fig.12: Five levels Flying Capacitor based Multilevel Inverter

\section{Merits of FCMLI are}

- If we go for higher levels, filter is not needed.

- Able to control the real and reactive power.

- It reduces the voltage stress across the devices.

Demerits are

- If no levels are high,huge amount of storage capacitor is needed.

- Bulky capacitors are expensive.

- Switching frequency as well as switching losses are high.

-Inverter control complexity increases.

DFIG output both voltage and frequency are controlled by operating the wind turbine at its maximum power point by implementing with Fuzzy logic controller and PI Controller. This model DFIG with FCMLI was developed in a Matlab/Simulink environment. FCMLI is controlled through sinusoidal PWM has been employed to measure desired electrical quantities for load and grid connection and THD and its individual harmonic contents are studied.

Table 2: Comparison of THD and Individual harmonic contents

\begin{tabular}{|c|c|c|c|c|c|c|c|c|c|c|c|c|}
\hline \multicolumn{2}{|c|}{ Model } & & \multicolumn{10}{|c|}{ Harmonic Order in $\%$} \\
\hline $\begin{array}{l}\text { Typ } \\
\text { e of } \\
\text { Con } \\
\text { vert } \\
\text { er }\end{array}$ & $\begin{array}{l}\text { Typ } \\
\text { e of } \\
\text { Con } \\
\text { troll } \\
\text { er }\end{array}$ & $\begin{array}{l}\mathrm{T} \\
\mathrm{H} \\
\mathrm{D} \\
\text { in } \\
\%\end{array}$ & $\begin{array}{l}\text { Fun- } \\
\text { dame } \\
\text { ntal }\end{array}$ & $\begin{array}{l}3 \\
r \\
d\end{array}$ & $\begin{array}{l}5^{t} \\
h\end{array}$ & $\begin{array}{l}7^{t} \\
h\end{array}$ & $\begin{array}{l}9^{t} \\
h\end{array}$ & $\begin{array}{l}l \\
1 t \\
h\end{array}$ & $\begin{array}{l}1 \\
3^{t} \\
h\end{array}$ & $\begin{array}{l}1 \\
5 t \\
h\end{array}$ & $\begin{array}{l}1 \\
7 t \\
h\end{array}$ & $\begin{array}{l}1 \\
9^{t} \\
h\end{array}$ \\
\hline \multirow{2}{*}{$\begin{array}{l}\mathrm{DC} \\
\mathrm{ML} \\
\mathrm{I}\end{array}$} & PI & $\begin{array}{l}3 . \\
6 \\
7\end{array}$ & 100 & $\begin{array}{l}0 . \\
9\end{array}$ & $\begin{array}{l}0 . \\
6\end{array}$ & $\begin{array}{l}0 . \\
5\end{array}$ & $\begin{array}{l}0 . \\
4\end{array}$ & $\begin{array}{l}0 . \\
3\end{array}$ & $\begin{array}{l}0 . \\
2\end{array}$ & $\begin{array}{l}0 . \\
1\end{array}$ & $\begin{array}{l}0 . \\
1 \\
5\end{array}$ & $\begin{array}{l}0 . \\
1 \\
0\end{array}$ \\
\hline & $\begin{array}{l}\text { FL } \\
\mathrm{C}\end{array}$ & $\begin{array}{l}0 . \\
0 \\
7\end{array}$ & 100 & $\begin{array}{l}0 . \\
0 \\
4\end{array}$ & $\begin{array}{l}0 . \\
0 \\
3\end{array}$ & $\begin{array}{l}0 . \\
0 \\
2\end{array}$ & $\begin{array}{l}0 . \\
0 \\
1\end{array}$ & $\begin{array}{l}0 . \\
0 \\
0\end{array}$ & $\begin{array}{l}0 . \\
0 \\
0\end{array}$ & $\begin{array}{l}0 . \\
0 \\
0\end{array}$ & $\begin{array}{l}0 . \\
0 \\
0\end{array}$ & $\begin{array}{l}0 . \\
0 \\
0\end{array}$ \\
\hline \multirow{2}{*}{$\begin{array}{l}\mathrm{FC} \\
\mathrm{ML} \\
\mathrm{I}\end{array}$} & PI & $\begin{array}{l}8 . \\
6\end{array}$ & 100 & $\begin{array}{l}6 . \\
2\end{array}$ & $\begin{array}{l}4 . \\
1\end{array}$ & $\begin{array}{l}4 . \\
0 \\
4\end{array}$ & $\begin{array}{l}3 . \\
2 \\
2\end{array}$ & $\begin{array}{l}3 . \\
0 \\
4\end{array}$ & $\begin{array}{l}2 . \\
8 \\
1\end{array}$ & $\begin{array}{l}1 . \\
9 \\
7\end{array}$ & $\begin{array}{l}1 . \\
0 \\
2\end{array}$ & $\begin{array}{l}0 . \\
8\end{array}$ \\
\hline & $\begin{array}{l}\text { FL } \\
\text { C }\end{array}$ & $\begin{array}{l}5 . \\
4\end{array}$ & 100 & $\begin{array}{l}3 . \\
9 \\
2\end{array}$ & $\begin{array}{l}2 . \\
5 \\
5\end{array}$ & $\begin{array}{l}2 . \\
1 \\
7\end{array}$ & $\begin{array}{l}1 . \\
6 \\
8\end{array}$ & $\begin{array}{l}1 . \\
4 \\
3\end{array}$ & $\begin{array}{l}1 . \\
2 \\
2\end{array}$ & $\begin{array}{l}1 . \\
1 \\
1\end{array}$ & $\begin{array}{l}0 . \\
9\end{array}$ & $\begin{array}{l}0 . \\
6\end{array}$ \\
\hline
\end{tabular}

\section{Conclusion}

Diode clamped multilevel inverter and flying capacitor clamped multilevel inverter based variable speed wind energy conversion system employing both PI controller and FLC were simulated and analyzed. The THD and its individual harmonic contents are measured through the FFT analysis in Simulink environment. The values were tabulated which shows that DCMLI has considerably less THD and its harmonic content compared to the FCMLI.

\section{References}

[1] Jyoti Mishra, Tripta Thakur and Guddy Satpathy, "Simulation of a Diode Clamped Multilevel Inverterin PMSG driven WECS", Impending Power Demand and Innovative Energy Paths,2015. 
[2] G.Balaji,I.Gnanambal,C.Gowrishankar, "Grid Connected WECS with A Five Level DCMLI using PID Controller", Middle-Eas Journal of Scientific Research, 2014.

[3] Kamil Antoniewicz, Marek Jasinski, Sebastian Stynski, "Flying Capacitor Converter as a wind turbine interface modulation and MPPT issues", IEEE International Symposium on Industrial Electronics, 2012.

[4] Mario Marchesoni, Pierluigi Tenca, "Diode-Clamped Multilevel Converters: A Practicable Way to Balance DC-Link Voltages," IEEE Transations on Industrial Electronics, Vol.49, No.4, August 2002.

[5] Xiaoming Yuan, Ivo Barbi, "Fundamentals of a New Diode Clamping Multilevel Inverter,'IEEE Transations on Power Electronics, Vol.15, No.4,July2000.

[6] Sayli Khadse,Rohini Mendole,Amarjeet Pandey, "A 5-Level Single Phase Flying Capacitor Multilevel Inverter,” International Research Journal of Engineering and Technology, Vol 04,Issue 02,Feb 2017.

[7] Miao Chang-xin,Shi Li-ping, Wang Tai-xu, Cui Cheng-bao, "Flying capacitor multilevel inverters with novel PWM method," The 6th International Conference on Mining Science \& Technology, 2009 .

[8] S. S. Das,S.C.Gupta,U.Rajkiran, "Harmonic Mitigation in Wind Eeergy Conversion System by Multilevel Inverter," International Journal of Electrical, Electronics and Data Communication, Vol 2, Issue 9,Sept 2014.

[9] Joshua Earnest,Tore Wizelius, “Wind Power Plants and Project Development,"PHI Learning 2011.

[10] Muhammad Rashid,“ Power Electronics Handbook,"Second Edition.

[11] G. Ramprabu, S. Nagarajan, "Design and Analysis of Novel Modified Cross Layer Controller for WMSN", Indian Journal of Science and Technology, Vol 8(5), March 2015, pp.438-444. 